\title{
INSTRUMENT MILITARNY POLITYKI ZAGRANICZNEJ PAŃSTWA
}

\author{
Ireneusz Topolski \\ Zakład Stosunków Międzynarodowych \\ Wydział Politologii, UMCS \\ Plac Litewski 3, 20-080 Lublin \\ e-mail: ireneusz.topolski@poczta.umcs.lublin.pl
}

\begin{abstract}
Streszczenie: Znaczenie siły militarnej po zakończeniu zimnej wojny zostało ograniczone. Jednocześnie zakres instrumentów militarnych ulegał stopniowemu rozszerzeniu. Znaczący wpływ na zaistniałą sytuację wywarł rozwój technologiczny i wprowadzanie nowych systemów uzbrojenia oraz wzrost znaczenia podmiotów niepaństwowych, które stanowią zagrożenie, w większym stopniu dla społeczeństw, niż samych państw. Kwestia ta przełożyła się na formę wykorzystania instrumentu militarnego w polityce zagranicznej państw.

Niniejszy artykuł zawiera analizę pojęcia ,instrument militarny”. Scharakteryzowane zostaną także formy wykorzystania instrumentu militarnego w polityce zagranicznej państwa. W niniejszym artykule poddano weryfikacji dwie hipotezy. Po pierwsze, formy wykorzystania instrumentu militarnego polityki zagranicznej państwa są dynamicznym procesem i ulegają stopniowemu poszerzeniu. Po drugie, mimo iż dominują pośrednie formy wykorzystania instrumentu militarnego, to jednak pojawiają się nowe możliwości, $\mathrm{w}$ tym związane $\mathrm{z}$ bezpośrednim użyciem sił zbrojnych o niskiej intensywności, tj. poniżej progu wojny.
\end{abstract}

Słowa kluczowe: państwo, polityka zagraniczna, instrumenty militarne

\section{POJĘCIE „INSTRUMENT MILITARNY”}

Według Słowniku Języka Polskiego, pojęcie ,instrument” definiuje się m.in. jako $^{1}$ :

a) przyrząd używany zwłaszcza do czynności wymagających precyzji;

b) środek służący do realizacji czegoś.

1 Słownik Języka Polskiego, URL <http://sjp.pwn.pl/lista.php?co=instrument> [dostęp: 11.07.2015]. 
Pojęcie ,instrument militarny” zawiera w swoim zakresie zarówno potencjał sił zbrojnych, jak też formacji paramilitarnych, przede wszystkim w kategoriach ilościowych i jakościowych. Obejmuje on:

a) stan wyposażenia i uzbrojenia;

b) poziom wykształcenia kadry dowódczej, a także wyszkolenia żołnierzy i funkcjonariuszy innych formacji paramilitarnych;

c) morale personelu wojskowego - zarówno żołnierzy, jak i funkcjonariuszy;

d) infrastrukturę techniczno-wojskową;

e) zaplecze logistyczne;

f) rozmieszczenie i mobilność jednostek wojskowych i innych grup, formacji należących do struktur siłowych. ${ }^{2}$

Ważną część sił zbrojnych stanowi wywiad i kontrwywiad, szczególnie wojskowy. W takim ujęciu instrument militarny należy również rozszerzyć o przemysł zbrojeniowy (kompleks militarno-przemysłowy), który po pierwsze, stanowi podstawę zaopatrywania własnych sił zbrojnych w niezbędną im technikę wojskową. Część gałęzi gospodarki państwa ${ }^{3}$, w tym zajmujących się tworzeniem nowoczesnych technologii jest $\mathrm{w}$ dużym stopniu ukierunkowana na zapewnienie sprawnego funkcjonowania sił zbrojnych. ${ }^{4}$ Po drugie, kompleks militarno-przemysłowy wytwarza także sprzęt wojskowy i systemy uzbrojenia, które są eksportowane do innych państw. W tym kontekście należy wskazać na rolę i znaczenie lobby zbrojeniowego w danym państwie. ${ }^{5}$

Charakter oraz możliwości wykorzystania instrumentów militarnych wynika z położenia geostrategicznego oraz przynależności do sojuszu obronnego (wojskowo-politycznego) danego państwa. ${ }^{6}$ Instrument militarny zazwyczaj jest

2 A. Czarnocki, Z. J. Pietraś, Wspótistnienie państw. Wstęp do międzynarodowych stosunków politycznych, Lublin 1988, s. 62; J. Kukułka, Międzynarodowe stosunki polityczne, Warszawa 1982, s. 45-46; I. Popiuk-Rysińska, Środki i metody polityki zagranicznej, [w:] Polityka zagraniczna państwa, J. Kukułka, R. Zięba (red.), Warszawa 1992, s. s. 87-89; E. Cziomer, L. W. Zyblikiewicz, Zarys współczesnych stosunków międzynarodowych, Warszawa 2006, s. 139; R. Łoś, Teoria stosunków międzynarodowych. Wybrane zagadnienia, Łódź 2001, s. 40-41; T. Łoś-Nowak, Stosunki międzynarodowe. Teorie - systemy - uczestnicy, Wrocław 2006, s. 280; T. Łoś-Nowak, Polityka zagraniczna, [w:] Współczesne stosunki międzynarodowe, T. Łoś-Nowak (red.), Wrocław 2008, s. 93; W. J. Dziak, Polityka wewnętrzna a polityka zagraniczna państwa, [w:] Nauka o polityce, A. Bodnar (red.), Warszawa 1988, s. 459; W. Szymborski, Międzynarodowe stosunki polityczne, Bydgoszcz 2008, s. 231; M. Dobroczyński, J. Stefanowicz, Polityka zagraniczna, Warszawa 1984, s. 69-74; R. Jackson, G. Sørensen, Wprowadzenie do stosunków międzynarodowych. Teorie i kierunki badawcze, Kraków 2006, s. 78; W. Malendowski, Zbrojenia, [w:] Stosunki międzynarodowe, W. Malendowski, Cz. Mojsiewicz (red.), Wrocław 2004, s. 433-438.

3 M. Dobroczyński, J. Stefanowicz, Polityka zagraniczna, s. 69-74.

4 W. Malendowski, Zbrojenia ..., s. 433-438; A. Wendt, Spoleczna teoria stosunków międzynarodowych, Warszawa 2008, s. 256-258; P. Skulski, Uwarunkowania komunikacji na międzynarodowym rynku uzbrojenia i sprzętu wojskowego, Wrocław 2013, s. 83-89.

5 P. Skulski, Uwarunkowania komunikacji..., s. 88.

6 E. Cziomer, L. W. Zyblikiewicz, Zarys wspótczesnych stosunków międzynarodowych, Warszawa 2006, s. 139; P. Żurawski vel Grajewski, Bezpieczeństwo międzynarodowe. Wymiar militarny, Warszawa 2012, s. 429-430. 
stosowany w polityce zagranicznej przez państwa w ostateczności, ale także w pewnych sytuacjach może przesądzić o wyniku konfrontacji. Po pierwsze, przede wszystkim w przypadku, gdy zawiodą lub nie będą wystarczająco skuteczne inne dostępne środki i metody. Po drugie, są wykorzystywane również jako wymuszona reakcja na nieprzyjazne działania innych państw. ${ }^{7}$ Po trzecie, państwa posługują się także instrumentami militarnymi w formie pomocy lub wsparcia dla swoich koalicjantów lub państw zaprzyjaźnionych. Jednak można wyróżnić jeszcze dwie opcje. Po czwarte, w sytuacji gdy państwa uznają, że użycie instrumentów militarnych jest możliwe i korzystne, w tym także, iż istnieje „odpowiednia atmosfera” na arenie międzynarodowej, co przyczyni się do realizacji ich interesów. Ponadto, po piąte decydenci mogą przyjąć, iż zastosowanie instrumentów militarnych stanowi najprostsze rozwiązanie, ale zarazem pociągające za sobą niskie koszty w porównaniu do innych instrumentów. ${ }^{8}$ Należy podkreślić, iż realizacja skutecznej i pokojowej polityki zagranicznej wymaga respektowania podstawowej zasady, a mianowicie, iż: „siły zbrojne nie rządzą polityką zagraniczną, lecz są jej instrumentem”. Oznacza to, że prowadzeniem polityki zagranicznej nie powinni się zajmować przedstawiciele struktur siłowych. ${ }^{9}$

Aby w pełni określić także specyfikę samego terminu ,instrument militarny”, należy oprzeć się na tzw. tetradzie, która obejmuje cztery podstawowe elementy, tj.: 1) podmioty; 2) zakres instrumentu militarnego; 3) forma wykorzystania instrumentu militarnego; 4) zakres przestrzenny. Po pierwsze, mimo iż polityka zagraniczna jest zarezerwowana dla państw, jednak w coraz większym stopniu na płaszczyźnie militarnej obejmuje podmioty niepaństwowe. Ponadto, rozszerza się spektrum instrumentu militarnego, w tym do celów wojskowych wykorzystuje się środki niemilitarne, tj. cywilne. Po trzecie, następuję adaptacja cywilnych form wykorzystania instrumentu militarnego. Czwarta kwestia odejmuje obszar działania, w tym przypadku nie ma określonego geograficznie terytorium, co więcej działania prowadzone są na terytorium własnego państwa.

7 R. Kuźniar, Międzynarodowe stosunki polityczne, [w:] Stosunki międzynarodowe. Geneza, struktura, dynamika, E. Haliżak, R. Kuźniar (red.), Warszawa 2004, s. 117-118; I. Popiuk-Rysińska, Środki..., s. 87-89; R. Łoś, Teoria..., s. 40-41; B. Balcerowicz, Obronność państwa średniego, Warszawa 1997, s. 66-68; J. Reginia-Zacharski, Wojna w świecie wspótczesnym. Uczestnicy - cele-modele-teorie, Łódź 2014, s. 280.

8 R. Vukadinowić, Międzynarodowe stosunki polityczne, Warszawa 1980, s. 334-341; J. Zając, Środki i metody polityki zagranicznej państwa, [w:] Wstęp do teorii polityki zagranicznej państwa, R. Zięba (red.), Toruń 2004, s. 88-90; J. Zając, Środki i metody oddziaływania USA w bliskowschodnim procesie pokojowy (1991-2000), Warszawa 2004, s. 22-24; J. Reginia-Zacharski, Wojna $w$ świecie współczesnym..., s. 280.

9 H. J. Morgenthau, przejrzał i uzupełnił K. W. Thompson, Polityka między narodami. Walka o potęge i pokój. Wydanie skrócone, Warszawa 2010, s. 379-380. 


\section{FORMY WYKORZYSTANIA INSTRUMENTU MILITARNEGO W POLITYCE ZAGRANICZNEJ PAŃSTWA}

Za podstawowe kryterium klasyfikacji przyjęto wyodrębnienie instrumentu militarnego w oparciu o bezpośrednie i pośrednie formy jego wykorzystania, przy jednoczesnym uwzględnieniu poziomu użycia siły - od zerowego, aż po bardzo wysoki. ${ }^{10} \mathrm{~W}$ XXI wieku klasyczny podział na te dwie kategorie nie oddaje istoty problemu, gdyż jest on bardziej złożony. Należy zaznaczyć, iż pewne formy znajdują się na pograniczu pośredniego i bezpośredniego wykorzystania instrumentu militarnego. Szczególnie kwestia ta dotyczy działań o niskiej intensywności - na progu wojny, które nie zawsze wiążą się z wkroczeniem na terytorium innego państwa. ${ }^{11}$ Ponadto, rozwój technologiczny z jednej strony prowadzi do powstania nowych rodzajów broni, z których część ma charakter w pewnym stopniu „cywilny”, m.in. broń psychotroniczna, komputery wykorzystywane do atakowania w cyberprzestrzeni. Po drugie, znacząco wpływa na pojawienie się nowych możliwości i ewolucję już istniejących form wykorzystania instrumentu militarnego w polityce zagranicznej państwa, w tym m.in. pod wpływem rozwoju broni masowego rażenia, przede wszystkim broni jądrowej oraz systemów bezza-

${ }^{10}$ A. Czarnocki, Z. J. Pietraś, Wspótistnienie ..., s. 62-63; R. Kuźniar, Międzynarodowe..., s. 117-118; R. Vukadinović, Międzynarodowe..., s. 334-341; J. Kukułka, Międzynarodowe..., s. 45-46; J. Kukułka, Zaspokajanie potrzeb i rozwiazywanie konfliktów w stosunkach międzynarodowych, [w:] Stosunki międzynarodowe: geneza, struktura, funkcjonowanie, E. Haliżak, R. Kuźniar (red), Warszawa 1994, s. 129-132; J. Kukułka, Wstęp do nauki o stosunkach międzynarodowych, Warszawa 2003, s. s. 169-172; I. Popiuk-Rysińska, Środki..., s. 87-89; E. Cziomer, L. W. Zyblikiewicz, Zarys ..., s. 139; R. Łoś, Teoria ..., s. 40-41; W. J. Dziak, Polityka..., s. 459; K. Sobczak, Niektóre środki polityki zagranicznej (próba charakterystyki), [w:] Teoretyczne problemy polityki zagranicznej, E. J. Pałyga, J. Symonides (red.), Warszawa 1978, s. 104-107; J. Stefanowicz, Anatomia polityki międzynarodowej, Toruń 1999, s. 104-106; B. Balcerowicz, Obronność..., s. 68-73; M. Dobroczyński, J. Stefanowicz, Polityka zagraniczna, Warszawa 1984, s. 69-74, 135-142; R. Bierzanek, Współczesne stosunki międzynarodowe, Warszawa 1980, s. 15, 56-62, 298-313, 319-337; W. Szymborski, Międzynarodowe..., s. 201; A. Wendt, Spoteczna teoria stosunków międzynarodowych, Warszawa 2008, s. 166-167, 244-248, 256-258, 327-328; M. Pietraś, Istota i ewolucja międzynarodowych stosunków politycznych, [w:] Międzynarodowe Stosunki Polityczne, M. Pietraś (red.), Lublin 2006, s. 21.

${ }^{11}$ J. Nowiak, Czym jest polityka zagraniczna, [w:] Stosunki międzynarodowe, W. Malendowski, Cz. Mojsiewicz (red.), Wrocław 2004, s. 81-82; J. Zając, Środki i metody polityki..., s. 88-90; J. Zając, Środki i metody oddziatywania..., s. 22-24; K. Sobczak, Niektóre..., s. 104; J. Stefanowicz, Anatomia..., s. 104-106; Cz. Maj, Podtyp B kapitalistycznego typu stosunków międzynarodowych, [w:] Wybrane problemy teorii i praktyki stosunków międzynarodowych, Z. J. Pietraś (red.), Lublin - Warszawa 1982, s. 155; M. Dobroczyński, J. Stefanowicz, Polityka ..., s. 135-142; S. Burchill, R. Devetak, A. Linklater, M. Paterson, Ch. Reus-Smit, J. True, Teorie stosunków międzynarodowych, Warszawa 2006, s. 53-55; R. Jackson, G. Sørensen, Wprowadzenie do stosunków międzynarodowych. Teorie i kierunki badawcze, Kraków 2006, s. 78, 85, 118-119, 138-139; B. Balcerowicz, Wybrane problemy obronności państwa. Materiaty studyjne, Warszawa 1999, s. 19-20, 56-64; B. Balcerowicz, Sojusz a obrona narodowa, Warszawa 1999, s. 20-25; A. Żebrowski, Wywiad i kontrwywiad XXI wieku, Lublin 2010, s. 263-267. 
łogowych. ${ }^{12}$ Pod wpływem rozwoju technologicznego, zmienia się sukcesywnie także sposób wykorzystaniu siły militarnej jako instrumentu polityki zagranicznej państwa. ${ }^{13}$ Transformacji uległ charakter walki tj. prowadzonych działań zbrojnych ale również przeciwnik, co wiąże się z pojawieniem się podmiotów nie będących państwami (niepaństwowych), które reprezentują nieregularne siły zbrojne lub formacjevoraz grupy terrorystyczne. Doszło także do przeorientowania celów politycznych oraz strategicznych, co przełożyło się na zmianę zastosowania-użycia siły militarnej. ${ }^{14} \mathrm{~W}$ konsekwencji obszar prowadzonych działań zbrojnych jest trudny do określenia, a celami ataku staje się ludność cywilna, która stanowi oparcie oraz podstawę możliwości funkcjonowania różnych grup zbrojnych, m.in. powstańców, rebeliantów, partyzantów, bojowników lub terrorystów. ${ }^{15}$ Należy także wskazać, iż nie wszystkie formy wykorzystania instrumentu militarnego są możliwe do zastosowania $\mathrm{w}$ danym okresie czasu lub obszarze wobec innego lub innych podmiotów. ${ }^{16}$ Ponadto, podmioty niepaństwowe - przeciwnik amorficzny - nie stwarzają bezpośredniego zagrożenia dla samych państw oraz ich terytoriów, ale grożą społeczeństwom, a przede wszystkim przyjętemu sposobowi życia i majątkowi mieszkańców. Sytuacja ta ma doprowadzić do wymuszenia zmiany zachowań i dążeń. ${ }^{17}$

Odrębny problem dotyczy udzielania pomocy w ramach zobowiązań sojuszniczych lub też wykorzystania sił wielonarodowych w ramach koalicji, w tym również przy uwzględnieniu operacji pokojowych. Uzupełnienie ich stanowi prowadzenie działalności wywiadowczej i kontrwywiadowczej przez służby specjalne państwa. ${ }^{18}$ Należy także zaznaczyć, iż poszczególne formy wykorzystania

${ }^{12}$ R. Kupiecki, K. Szczepanik, Polityka zagraniczna Polski 1918-1994, Warszawa 1995, s. 12; W. Malendowski, Zbrojenia, [w:] Stosunki międzynarodowe, W. Malendowski, Cz. Mojsiewicz (red.), Wrocław 2004, s. 433-441; J. Wiatr, Zarys nauki o stosunkach międzynarodowych, Warszawa 2008, s. 13-17; J. Wiatr, Współczesne stosunki międzynarodowe: wybrane zagadnienia, Koszalin 2002, s. 37-4; M. Boguta, Wptyw rozwoju nauki i techniki na wspótczesne stosunki międzynarodowe, [w:] Stosunki międzynarodowe. Problemy badań i teorii, A. Bodnar, W. J. Szczepański (red.), Warszawa 1983, s. 401-402; A. Wendt, Społeczna ..., s. 109; R. Szpyra, Bezpieczeństwo militarne państwa, Warszawa 2012, s. 48-60, 72-74; M. van Creveld, Zmienne oblicza wojny. O Marny do Iraku, Poznań 2008, s. 302-303; Ł. Kamieński, Technologia i wojna przyszłości. Wokót nuklearnej i informacyjnej rewolucji w sprawach wojskowych, Kraków 2009, s. 23 i nast.

13 J. S. Nye jr., Konflikty międzynarodowe. Wprowadzenie to teorii i historii, Warszawa 2009, s. 34-36; J. J. Piątek, Narzędzia wojny i ich wspótczesny rozwój (wybrane aspekty dla XX wieku), Toruń 2009, s. 9 i nast.; R. Smith, Przydatność sity militarnej. Sztuka wojenna we wspótczesnym świecie, Warszawa 2010, s. 4470-473.

${ }^{14}$ R. Smith, Przydatnośćc..., s. 21-51, 319-363, 389-392, 469-473.

${ }^{15}$ R. Smith, Przydatność..., s. 332-363.

${ }^{16}$ R. Smith, Przydatność..., s. 364-392.

${ }^{17}$ R. Smith, Przydatność..., s. 440-441.

${ }^{18}$ R. Kuźniar, Międzynarodowe..., s. 117-118; I. Popiuk-Rysińska, Środki..., s. 87-89, 91; E. Cziomer, L. W. Zyblikiewicz, Zarys..., s. 139; R. Łoś, Teoria ..., s. 40-41; J. Zając, Środki i metody polityki..., s. 88-90, 94-97; J. Zając, Środki i metody oddzialywania..., s. 22-24, 28-30, 141-142; E. J. Pałyga, Uczestnicy stosunków międzynarodowych, [w:] Wybrane problemy teorii 
instrumentu militarnego wzajemnie zazębiają się, a w przypadku części z nich granica jest płynna. Uwzględniając powyższe kwestie, wyodrębniono czternaście form wykorzystania instrumentu militarnego w polityce zagranicznej państwa. Zalicza się do nich:

1. Odstraszanie potencjałem militarnym.

2. Demonstrację siły militarnej, w tym także jej gotowości bojowej.

3. Eksport techniki wojskowej oraz nowoczesnych technologii.

4. Przejmowanie lub inwestycje kapitałowe w przedsiębiorstwach zbrojeniowych innych państw oraz kooperacja przedsiębiorstw zbrojeniowych.

5. Sterowanie własnym potencjałem militarnym.

6. Kontrola i redukcja zbrojeń.

7. Obecność wojskowa poza granicami państwa.

8. Pomoc wojskowa.

9. Groźba użycia siły.

10. Ograniczone użycie siły zbrojnej.

11. Wykorzystanie środków walki informacyjnej.

12. Użycie siły zbrojnej.

13. Udział w operacjach pokojowych.

14. Działalność wywiadowcza.

Dwie ostatnie formy, znajduje się na pograniczu analizowanego problemu, gdyż dotyczą specyficznego wykorzystania instrumentu militarnego państwa. Jednak ze względu na charakter i rozwój współczesnych operacji pokojowych, w tym interwencji zbrojnej i w celach humanitarnych, zasadne wydaje się zaliczenie jej do form wykorzystania instrumentu militarnego. Ponadto, mimo pojawiających się kontrowersji, należy wywiad do instrumentu militarnego. Za przyjęciem takiego rozwiązania przemawia uzasadnienie o istniejących powiązaniach wywiadu oraz kontrwywiadu z armią, w której ramach może się znajdować. Ponadto należy także wskazać na duże znaczenie struktur wywiadu dla prawidłowego funkcjonowania współczesnych siły zbrojnych.

1. Odstraszanie potencjałem militarnym. W wąskim rozumieniu tylko samo posiadanie odpowiedniego potencjału militarnego, spełnia funkcję odstraszającą, która ma na celu odwieść przeciwnik od podjęcia na arenie międzynarodowej pewnych określonych działań lub ich zaniechania. Zachowanie takie ma uchronić go przed wykorzystaniem „niszczycielskiego” potencjału przez określone mocarstwo, co jest też zaznaczane jako warunkowa groźba użycia siły. Z drugiej zaś zakłada wymuszenie, tj. „nakłonienie” innego państwa do wykonania kroków, których niekoniecznie jest skłonne zaakceptować, ze względu na zabezpieczenie interesów narodowych oraz obronę własnej suwerenności. Istota odstraszania polega na zniechęceniu przeciwnika do podjęciach określonych działań poprzez wzbudzenie u niego strachu. Szczególnie jest to widoczne w przy-

i praktyki stosunków międzynarodowych, Z. J. Pietraś (red.), Lublin - Warszawa 1982, s. 79-82; M. Dobroczyński, J. Stefanowicz, Polityka ..., s. 69-74; R. Smith, Przydatność..., s. 40, 326-331. 
padku odstraszania (zastraszania) nuklearnego. Funkcję odstraszającą mogą spełniać także strategiczne bronie defensywne, do których zalicza się system obrony antyrakietowej lub systemy antyrakietowe rozmieszczone w przestrzeni kosmicznej oraz systemy antysatelitarne. W przypadku zaś mniejszych państw należy wskazać na kwestię zniechęcenia potencjalnego agresora, który w sytuacji podjęcia ataku musi uwzględnić poniesione straty, które mogą być wysokie wobec potencjalnych korzyści. ${ }^{19}$ Skuteczność odstraszania poza dysponowaniem odpowiednim potencjałem militarnym, wymaga spełnienia jeszcze dwóch zasadniczych punktów. Po pierwsze gotowości posłużenia się nim, tj. określenie celów, którym zagrażamy. Po drugie, przeciwnik musi uwierzyć, iż dane państwo jest gotowe - ma wolę i determinację - spełnić swoją groźbę oraz posiada możliwości militarne do wykonania przyjętych zamierzeń. ${ }^{20}$ Dysponowanie potencjałem militarnym stanowi także środek nacisku na inne państwa lub też ma na celu wzmocnienie własnej pozycji przetargowej. ${ }^{21}$

${ }^{19}$ A. Czarnocki, Z. J. Pietraś, Wspótistnienie..., s. 61-64; R. Kuźniar, Międzynarodowe stosunki polityczne..., s. 117-118; R. Vukadinović, Międzynarodowe stosunki polityczne, Warszawa 1980, s. 334-341; J. Kukułka, Zaspokajanie potrzeb i rozwiazywanie konfliktów w stosunkach międzynarodowych, [w:] Stosunki międzynarodowe: geneza, struktura, funkcjonowanie, E. Haliżak, R. Kuźniar (red), Warszawa 1994, s. 129-132; I. Popiuk-Rysińska, Środki i metody polityki zagranicznej, [w:] Polityka zagraniczna państwa, J. Kukułka, R. Zięba (red.), Warszawa 1992, s. 87-89; E. Cziomer, L. W. Zyblikiewicz, Zarys..., s. 139; R. Łoś, Teoria stosunków międzynarodowych. Wybrane zagadnienia, Łódź 2001, s. 40-41; J. Nowiak, Czym jest polityka zagraniczna, [w:] Stosunki międzynarodowe, W. Malendowski, Cz. Mojsiewicz (red.), Wrocław 2004, s. 81; T. Łoś-Nowak, Stosunki międzynarodowe. Teorie - systemy - uczestnicy, Wrocław 2006, s. 273-278; T. Łoś-Nowak, Polityka zagraniczna, [w:] Wspótczesne stosunki międzynarodowe, T. Łoś-Nowak (red.), Wrocław 2008, s. 89-91; J. Zając, Środki i metody polityki zagranicznej państwa, [w:] Wstęp do teorii polityki zagranicznej państwa, R. Zięba (red.), Toruń 2004, s. 88-90; J. Zając, Środki i metody oddziaływania USA w bliskowschodnim procesie pokojowy (1991-2000), Warszawa 2004, s. 22-24; K. Sobczak, Niektóre środki polityki zagranicznej (próba charakterystyki), [w:] Teoretyczne problemy polityki zagranicznej, E. J. Pałyga, J. Symonides (red.), Warszawa 1978, s. 102-104; J. Stefanowicz, Anatomia polityki międzynarodowej, Toruń 1999, s. 104-106; M. Dobroczyński, J. Stefanowicz, Polityka ..., s. 69-74, 135-142; R. Bierzanek, Współczesne..., s. 298-313, 335-337; R. Jackson, G. Sørensen, Wprowadzenie..., s. 86, 93-95, 138-139, 165; W. Szymborski, Międzynarodowe stosunki polityczne, Bydgoszcz 2008, s. 231; K. Mingst, Podstawy stosunków międzynarodowych, Warszawa 2008, s. 121-122; R. Aron, Pokój $i$ wojna między narodami, Warszawa 1995, s. 62-98; J. S. Nye jr., Konflikty międzynarodowe. Wprowadzenie..., s. 48-49, 100, 201-215; C. Dale Walton, C. S. Gray, Druga epoka nuklearna: broń jądrowa w XXI wieku, [w:] Strategia we wspótczesnym świecie. Wprowadzenie do studiów strategicznych, J. Baylis, J. Wirtz, C. S. Gray, E. Cohen (red.), Kraków 2009, s. 226-229, 234-237, 240-243; R. Szpyra, Bezpieczeństwo militarne państwa ..., s. 173-188; H. J. Morgenthau, przejrzał i uzupełnił K. W. Thompson, Polityka..., s. 145-149,282-286; M. van Creveld, Zmienne..., s. 215-223; R. Smith, Przydatność..., s. 232-234,; Ł. Kamieński, Technologia ..., s. 92-208.

${ }^{20}$ R. Smith, Przydatnośćc..., s. 444-445, 449-450.

${ }^{21}$ B. White, Dyplomacja, [w:] Globalizacja polityki światowej. Wprowadzenie do stosunków międzynarodowych, J. Baylis, S. Smith (red), Kraków 2008, s. 490-493; Kuźniar, Międzynarodowe stosunki polityczne..., s. 117-118; E. Cziomer, L. W. Zyblikiewicz, Zarys..., s. 139; R. Łoś, Teoria stosunków międzynarodowych ..., s. 40-41; B. Balcerowicz, Obronność..., s. 68-73; J. Baylis, 
2. Demonstracja sily militarnej, w tym także jej gotowości bojowej. ${ }^{22}$ Po pierwsze, obejmuje ona publiczną prezentację nowych typów uzbrojenia (m.in. poprzez parady wojskowe), defilady wojskowe, przeprowadzania prób z nowymi systemami uzbrojenia, czy też ćwiczenia (manewry) z nową bronią. ${ }^{23}$ Po drugie, przeprowadzanie różnych manewrów wojskowych, w tym również w strefie przygranicznej oraz w pobliżu morza terytorialnego. Po trzecie, koncentracja wojsk $\mathrm{w}$ regionach przygranicznych, a także rozmieszczenie sił zbrojnych $\mathrm{w}$ punktach strategicznych lub w pobliżu granic lądowych, morskich lub przestrzeni powietrznej innych państw. Towarzyszyć temu może także gotowość do podjęcia działań przez oddziały wojskowe. Należ również dodać oficjalne lub kurtuazyjne wizyty okrętów wojennych, a także samolotów bojowych, czy jednostek sił lądowych na terytorium innych państw, których celem jest prezentacja potęgi militarnej. ${ }^{24} \mathrm{Po}$ czwarte, mobilizacja wojsk, w tym rezerwistów w okresie napięć. ${ }^{25}$

3. Transfer (tzn. eksport oraz import) techniki wojskowej oraz nowoczesnych technologii o przeznaczeniu militarnym, co wiąże się z dostawą uzbrojenia i wyposażenia dla sił zbrojnych zazwyczaj w formie sprzedaży, dzierżawy, leasingu. Do tej kategorii należy zaliczyć także transfer nowoczesnych technologii militarnych, jak równie sprzedaż licencji na produkcję broni w innym państwie. $Z$ drugiej strony, wiąże się z pozyskiwaniem uzbrojenia i nowoczesnych technologii o charakterze wojskowym. W tym punkcie należy także uwzględnić technologie podwójnego przeznaczenia oraz produkty (towary) o podwójnym cywilno-militarnym zastosowaniu. ${ }^{26}$ Jego uzupełnienie stanowi system kompensacji (offset) mający na celu, m.in. inwestycje lub przekazanie nowoczesnych tech-

M. Smith, Kontrola broni masowej zagłady, [w:] Strategia we wspótczesnym świecie. Wprowadzenie do studiów strategicznych, J. Baylis, J. Wirtz, C. S. Gray, E. Cohen (red.), Kraków 2009, s. 258.

${ }^{22}$ J. Kukułka, Wstęp do nauki o stosunkach międzynarodowych..., s. 169-172.

${ }^{23}$ I. Popiuk-Rysińska, Środki i metody polityki zagranicznej..., s. 87-89; R. Łoś, Teoria stosunków międzynarodowych..., s. 40-41; W. J. Dziak, Polityka wewnętrzna a polityka zagraniczna państwa, [w:] Nauka o polityce, A. Bodnar (red.), Warszawa 1988, s. 459; K. Sobczak, Niektóre środki polityki zagranicznej ..., s. 102-104; H. J. Morgenthau, przejrzał i uzupełnił K. W. Thompson, Polityka ..., s. 104-106.

${ }^{24}$ I. Popiuk-Rysińska, Środki i metody polityki zagranicznej..., s. 87-89; W. J. Dziak, Polityka wewnętrzna ..., s. 459; K. Sobczak, Niektóre środki polityki zagranicznej..., s. 102-104; K. Derwich, Instrumenty polityki zagranicznej USA wobec państw Ameryki Łacińskiej 1945-2000, Kraków 2010, s. 69, 97; H. J. Morgenthau, przejrzał i uzupełnił K. W. Thompson, Polityka..., s. 104-106.

${ }^{25}$ I. Popiuk-Rysińska, Środki i metody polityki zagranicznej..., s. 87-89; R. Łoś, Teoria stosunków międzynarodowych..., s. 40-41; K. Sobczak, Niektóre środki polityki zagranicznej..., s. 102-104; H. J. Morgenthau, przejrzał i uzupełnił K. W. Thompson, Polityka ..., s. 104-106.

${ }^{26}$ J. Kukułka, Wstęp do nauki o stosunkach międzynarodowych..., s. 169-172; W. Szymborski, Międzynarodowe..., s. 231; M. Pietraś, Istota i ewolucja międzynarodowych stosunków politycznych, [w:] Międzynarodowe Stosunki Polityczne, M. Pietraś (red.), Lublin 2006, s. 21; P. Skulski, Uwarunkowania komunikacji..., s. 94-97, 104-108, 116-119, 120-315; W. D. Hartung, Międzynarodowy handel bronia, [w:] Studia bezpieczeństwa, P. D. Williams (red.), Kraków 2012, s. 346-361; R. Smith, Przydatność..., s. 112-113. 
nologii państwu importerowi. W dalszej perspektywie eksport uzbrojenia może wiązać się, także z obecnością doradców lub specjalistów odpowiedzialnych za szkolenie personelu państwa importera oraz serwis systemów uzbrojenia i wyposażenia, w tym dostawę części zamiennych. W konsekwencji instrument ten może służyć do zdobycia, zachowania lub umocnienia wpływów w państwie-odbiorcy, pozyskania sojuszników. Natomiast importerzy w zamian mogli zaoferować udostępnienie baz wojskowych, czy też ochronę interesów państwa-dostawcy. Ważną kwestię stanowi również lobbing ze strony dostawcy u potencjalnego importera. $\mathrm{W}$ pewnych sytuacjach jest on prowadzony także przez przedstawicieli władz państw, w tym głowę państwa, szefa rządu i innych członków gabinetu, włączając m.in. z ministrów spraw zagranicznych i oraz obrony. ${ }^{27}$

4. Przejmowanie lub inwestycje kapitalowe w przedsiębiorstwach zbrojeniowych innych państw, poprzez prywatyzację lub konsolidację. Do form związanych z łączeniem firm zalicza się fuzje, wykup (przejęcie), wzajemne posiadanie (wymianę) akcji. Kooperacja wiąże się w dalszej perspektywie czasowej z lokowaniem produkcji poszczególnych elementów lub nawet całych systemów uzbrojenia w zakładach produkcyjnych na terytorium innego państwa. Po drugie, współpraca zakładów przemysłu zbrojeniowego z różnych państw, w dużej części jako podwykonawcy. Kooperacja przemysłowa firm zbrojeniowych z różnych państw ma na celu ograniczenie kosztów opracowania nowych systemów techniki wojskowej oraz współzależności technologicznych. ${ }^{28}$

5. Sterowanie własnym potencjałem militarnym, co wiąże się z posiadaniem odpowiedniej jego wielkości oraz możliwości manipulowania nim. Po pierwsze, dysponowanie adekwatnym potencjałem militarnym podnosi prestiż państwa na arenie międzynarodowej, a także jest symbolem jego potęgi. Wysoką pozycję z środowisku międzynarodowym zajmują mocarstwa nuklearne USA, Rosja, Chiny, W. Brytania i Francja. Natomiast cztery państwa, które dysponują bronią jądrową, ale nie są uznane przez Układ o Nieproliferacji Broni Nuklearnej z 1967 r. za mocarstwa nuklearne, tj. Indie, Izrael, Pakistan, Korea Północna także starają się wykorzystać jej atuty w polityce zagranicznej. ${ }^{29}$ Ponadto, rozbudo-

${ }^{27}$ P. Skulski, Uwarunkowania komunikacji..., s. 121-315; W. D. Hartung, Międzynarodowy..., s. 348-353.

${ }^{28}$ P. Skulski, Uwarunkowania komunikacji..., s. 106-119, 123-125, 147-159.

${ }^{29}$ A. Czarnocki, Z. J. Pietraś, Wspótistnienie..., s. 61-64; R. Vukadinović, Międzynarodowe..., s. 334-341; J. Nowiak, Czym jest polityka zagraniczna..., s. 81; J. Zając, Środki i metody polityki zagranicznej państwa..., s. 88-90; J. Zając, Srodki i metody oddziaływania USA ..., s. 22-24; R. Bierzanek, Wspótczesne ..., s. 56-62; J. S. Nye jr., Konflikty międzynarodowe. Wprowadzenie..., s. 100, 371-375; M. Sheehan, Ewolucja nowoczesnych wojen, [w:] Strategia we wspótczesnym świecie. Wprowadzenie do studiów strategicznych, J. Baylis, J. Wirtz, C. S. Gray, E. Cohen (red.), Kraków 2009, s. 62-64; E. Cohen, Wojna i technologie, [w:] Strategia we współczesnym świecie. Wprowadzenie do studiów strategicznych, J. Baylis, J. Wirtz, C. S. Gray, E. Cohen (red.), Kraków 2009, s. 165; C. Dale Walton, C. S. Gray, Druga epoka nuklearna ..., s. 231-233, 236-237, 240-243; J. Baylis, M. Smith, Kontrola broni masowej zagłady, [w:] Strategia we współczesnym świecie. Wprowadzenie do studiów strategicznych, J. Baylis, J. Wirtz, C. S. Gray, E. Cohen (red.), 
wa samego potencjału militarnego ma na celu utrzymanie lub wzrost pozycji militarnej państwa. Kwestia ta jest powiązana ze zwiększaniem wydatków wojskowych. ${ }^{30} \mathrm{~W}$ tym kontekście istnieje możliwość przedstawienia międzynarodowej pozycji militarnej danego państwa/ państw, zarówno w skali regionu lub też szerzej na poziomie globalnym.

Po drugie, manipulowanie potencjałem militarnym, do którego zalicza się jednostronne decyzje państwa nie poparte porozumieniami międzynarodowymi odnośnie, m.in. redukcji potencjału sił zbrojnych, przyjęcia określonych zobowiązań, np. moratorium na doświadczenia z bronią jądrową. Działania w tym zakresie obejmują również rozbudowę własnych sil zbrojnych, m.in. poprzez prowadzenie prac naukowo-badawczych nad nowymi systemami techniki wojskowej. Ponadto produkcja i wprowadzanie nowoczesnego uzbrojenia i wyposażenia, w tym także tzw. „,bronie inteligentne” oraz „przyszłości” na stan sił zbrojnych. Działania te określa się jako polityka zbrojeń, które mogą prowadzić do wyścigu - spirali - zbrojeń. Przejawia się to poprzez zwiększanie nakładów finansowych na cele militarne, tj. wydatków wojskowych, a szczególnie nakładów zbrojeniowych. ${ }^{31}$

6. Kontrola i redukcja zbrojeń $\mathrm{w}$ ramach porozumień międzynarodowych wiąże się z udziałem i poziomem zaangażowania państw w procesie ograniczania potencjału militarnego lub nieprzystępowania, zawieszania, wycofywania się (wystąpienia) z tych układów rozbrojeniowych. Głównym celem kontroli i redukcji zbrojeń jest powstrzymanie zbrojeń na poziomie globalnym lub regionalnym państw, czy też wyeliminowanie, tj. stopniowa likwidacja określonych

Kraków 2009, s. 266-269; J. N. Shapiro, R. P. Darken, Bezpieczeństwo wewnętrzne: nowy paradygmat strategiczny, [w:] Strategia we wspótczesnym świecie. Wprowadzenie do studiów strategicznych, J. Baylis, J. Wirtz, C. S. Gray, E. Cohen (red.), Kraków 2009, s. 334-335; W. P. Singh Sidhu, Proliferacja broni jądrowej, [w:] Studia bezpieczeństwa, P. D. Williams (red.), Kraków 2012, s. 363-375; M. van Creveld, Zmienne ..., s. 223-231; R. Smith, Przydatność..., s. 476; Ł. Kamieński, Technologia..., s. 160-204, 294-336.

${ }^{30}$ R. Vukadinović, Międzynarodowe..., s. 334-341; J. Kukułka, Międzynarodowe stosunki polityczne, Warszawa 1982, s. 45-46; M. Dobroczyński, J. Stefanowicz, Polityka ..., s. 69-74; J. Kukułka, Wstęp do nauki o stosunkach międzynarodowych, Warszawa 2003, s. 61-62; J. J. Wirtz, Nowy program bezpieczeństwa i strategii?, [w:] Strategia we wspótczesnym świecie. Wprowadzenie do studiów strategicznych, J. Baylis, J. Wirtz, C. S. Gray, E. Cohen (red.), Kraków 2009, s. 379-381; S. Burchill, R. Devetak, A. Linklater, M. Paterson, Ch. Reus-Smit, J. True, Teorie..., s. 97-98, 111, 114, 117; P. Skulski, Uwarunkowania komunikacji..., s. 78-83.

${ }^{31}$ R. Kuźniar, Międzynarodowe stosunki polityczne..., s. 117-118; I. Popiuk-Rysińska, Środki i metody polityki zagranicznej..., s. 87-89; R. Łoś, Teoria stosunków międzynarodowych..., s. 40-41; M. Dobroczyński, J. Stefanowicz, Polityka ..., s. 135-142; W. Malendowski, Zbrojenia ..., s. 433-441; A. Wendt, Społeczna ..., s. 256-258; J. Ferris, Sity konwencjonalne we współczesnej wojnie, [w:] Strategia we współczesnym świecie. Wprowadzenie do studiów strategicznych, J. Baylis, J. Wirtz, C. S. Gray, E. Cohen (red.), Kraków 2009, s. 280-281; P. Skulski, Uwarunkowania komunikacji..., s. 72-83; H. J. Morgenthau, przejrzał i uzupełnił K. W. Thompson, Polityka..., s. 200; K. Booth, N. J. Wheeler, Niepewność, [w:] Studia bezpieczeństwa, P. D. Williams (red.), Kraków 2012, s. 142-143. 
systemów uzbrojenia. Ponadto, należy również uwzględnić kwestię kontroli handlu uzbrojeniem konwencjonalnym. ${ }^{32}$

7. Obecność wojskowa poza granicami państwa, zarówno poprzez rozmieszczenie jednostek na stałe, jak również czasowe przebywanie na terytorium innych państw lub w miejscach strategicznych. W pierwszym przypadku należy uwzględnić utrzymanie i wykorzystanie baz wojskowych, portów wojennych oraz instalacji militarnych, w tym m.in. systemów wczesnego ostrzegania, węzłów łączności, lotnisk, szlaków komunikacyjnych, ale również dyslokację tylko uzbrojenia i sprzętu wojskowego na terytorium innych państw. Sama obecność wojskowa może ograniczać się wyłącznie do wykorzystania infrastruktury wojskowej. Natomiast czasowe bazowanie wiąże się m.in. z dyslokacją połączoną z rotacyjnymi patrolami morskimi lub lotniczymi, przeprowadzeniem wspólnych manewrów, wizytami okrętów i personelu w portach wojennych lub jednostkach wojskowych, czy też innymi kontaktami z wojskowymi drugiego państwa. Utrzymanie obecności wojskowej poza granicami państwa, zarówno stałej jak i czasowej z jednej strony, ma na celu powstrzymanie ewentualnego agresora od podjęcia nieprzyjaznych działań, w tym również wobec państw sprzymierzonych i zaprzyjaźnionych - rola prewencyjna i ochronna. Po drugie, obejmuje pomoc i/ lub wsparcie dla sojuszników i ważnych partnerów, co przyczynia się do zapewnienia bezpieczeństwa narodowego państwa wysyłającego oraz wzrostu stabilności i pokoju na poziomie regionalnym. Zapewnienie bezpieczeństwa militarnego koalicjanta poprzez obecność wojskową może przyczynić się do uzyskania wpływów politycznych oraz gospodarczych w tym państwie. ${ }^{33}$

8. Pomoc wojskowa, przekazywana m.in. sojusznikom, państwom zaprzyjaźnionym, ruchom opozycyjnym i narodowo-wyzwoleńczym, może także mieć na celu pozyskanie przychylności władz oraz elit wojskowych przede wszystkim w państwach, w których struktury siłowe zajmują ważne miejsce w polityce wewnętrznej..$^{34}$ Udzielana się jej w różnej formie. Po pierwsze, poprzez nieodpłatne

${ }^{32}$ J. Zając, Środki i metody polityki zagranicznej państwa..., s. 88-90; J. Zając, Środki i metody oddziaływania USA..., s. 22-24; M. Dobroczyński, J. Stefanowicz, Polityka..., s. 69-74, 135-142; R. Bierzanek, Wspótczesne ..., s. 319-337; M. Pietraś, Istota i ewolucja międzynarodowych stosunków politycznych..., s. 21; J. Baylis, M. Smith, Kontrola broni masowej..., s. 251256; P. Skulski, Uwarunkowania komunikacji..., s. 181-193; P. Żurawski vel Grajewski, Bezpieczeństwo międzynarodowe..., s. 301-308, 327-371; H. J. Morgenthau, przejrzał i uzupełnił K. W. Thompson, Polityka ..., s. 277-286; W. P. Singh Sidhu, Proliferacja ..., s. 365-375.

33 J. Zając, Środki i metody polityki zagranicznej państwa..., s. 88-90; J. Zając, Środki i metody oddziaływania USA..., s. 22-24; E. J. Pałyga, Uczestnicy stosunków międzynarodowych, [w:] Wybrane problemy teorii i praktyki stosunków międzynarodowych, Z. J. Pietraś (red.), Lublin Warszawa 1982, s. 79-82; Cz. Maj, Podtyp B kapitalistycznego typu stosunków międzynarodowych, [w:] Wybrane problemy teorii i praktyki stosunków międzynarodowych, Z. J. Pietraś (red.), Lublin - Warszawa 1982, s. 155; R. Jackson, G. Sørensen, Wprowadzenie ..., s. 209; D. Majchrzak, Bezpieczeństwo militarne Polski, Warszawa 2015, s. 58-59.

${ }^{34}$ I. Popiuk-Rysińska, Środki i metody polityki zagranicznej ..., s. 87-89; R. Łoś, Teoria stosunków międzynarodowych ..., s. 40-41; J. Zając, Środki i metody polityki zagranicznej państwa..., 
dostawy - również nielegalne - uzbrojenia, sprzętu i wyposażenia wojskowego. Druga forma obejmuje organizowanie i prowadzenie szkoleń, kursów i ćwiczeń dla personelu, tj. członków korpusu oficerskiego, żołnierzy sił zbrojnych i funkcjonariuszy policji oraz innych formacji paramilitarnych państwa-gospodarza. Należy także uwzględnić doradztwo w sprawach militarnych realizowane przez żołnierzy, instruktorów i ekspertów wojskowych, m.in. włącznie z planowaniem operacji wojskowych. Zespoły doradczo-szkoleniowe mogą koncentrować się także na działaniach, które mają na celu umocnienie jego bezpieczeństwa wewnętrznego. Stanowią również swego rodzaju źródło informacji o siłach zbrojnych i o polityce wewnętrznej państwa-odbiorcy. Ponadto, mogą również sugerować władzom tegoż państwa zakup „określonych” systemów techniki wojskowej. Po trzecie udostępnianie informacji (w tym wywiadowczych) o znaczeniu militarnym..$^{35}$ Po czwarte przekazywanie środków finansowych (pomoc bezzwrotna w formie dotacji, kredytów), jak również udzielanie pożyczek lub grantów na preferencyjnych zasadach na zakup techniki wojskowej we własnych przedsiębiorstwach. Inny charakter ma sprzedaż broni na dogodnych warunkach, czy też jej leasing. ${ }^{36}$ Udzielanie pomocy wojskowej może prowadzić do powstania ściślejszych powiązań z korpusem oficerskim $\mathrm{w}$ armii, a to przekłada się także ustanowienie obecności i wpływów politycznych w państwie odbiorcy „usług” wojskowych. Należy także wskazać powiązania personalne, gdyż część uczestników szkoleń piastuje ważne stanowiska w siłach zbrojnych, innych strukturach siłowych lub aparacie władzy państwowej. Ponadto pomoc wojskowa niekiedy przyczynia się do zmniejszenia zdolności bojowej lub ograniczenia możliwości użycia potencjału militarnego państwa-biorcy, czy też prowadzenia samodzielnych działań przez własną armię lub struktury siłowe. Problem ten może wynikać z tzw. „uzależnienia się” od pomocy wojskowej z zewnątrz, czy też „spenetrowania" struktur dowodzenia przez donatora. Państwo darczyńca, w zamian za świadczenie „usług o charakterze militarnym” może uzyskać, jako „rekompensatę" możliwość użytkowania baz lub infrastruktury wojskowej na terytorium państwa odbiorcy. ${ }^{37}$

s. 88-90; J. Zając, Środki i metody oddziaływania USA ..., s. 22-24; M. Dobroczyński, J. Stefanowicz, Polityka..., s. 135-142; K. Derwich, Instrumenty ..., s. 91-127.

${ }^{35}$ I. Popiuk-Rysińska, Środki i metody polityki zagranicznej..., s. 87-89; R. Kuźniar, Międzynarodowe stosunki polityczne..., s. 117-118; E. Cziomer, L. W. Zyblikiewicz, Zarys ..., s. 139; J. Zając, Środki i metody polityki zagranicznej państwa..., s. 88-90; J. Zając, Środki i metody oddziatywania USA..., s. 22-24, 141-142; Cz. Maj, Podtyp B kapitalistycznego typu..., s. 155; M. Dobroczyński, J. Stefanowicz, Polityka ..., s. 69-74, 135-142; K. Derwich, Instrumenty..., s. 97-127, 192-202; P. Skulski, Uwarunkowania komunikacji..., s. 142-147.

${ }^{36}$ J. Zając, Środki i metody polityki zagranicznej państwa..., s. 88-90; J. Zając, Środki i metody oddziatywania USA ..., s. 22-24, 141-142; P. Skulski, Uwarunkowania komunikacji..., s. $143-147$.

${ }^{37}$ I. Popiuk-Rysińska, Środki i metody polityki zagranicznej..., s. 87-89; R. Łoś, Teoria stosunków międzynarodowych ..., s. 40-41; J. Zając, Środki i metody polityki zagranicznej państwa..., s. 88-90; J. Zając, Środki i metody oddziaływania USA ..., s. 22-24, 141-142. 
9. Groźba użycia siły, jest również określana jako wymuszanie. Należy zaznaczyć, że granica między wymuszaniem, określanym także jako przymuszanie, a odstraszaniem nie jest ściśle wyznaczona. Obie te formy mogą zazębiać się. Zgodnie z zasadą, iż groźba wyrządzenie ,potencjalnej” szkody ma za zadanie skłonienie innego państwa do wykonania, ewentualnie zaniechania pewnych działań, ustępstw lub podporządkowania się, bez użycia siły militarnej. Trzy kwestie wpływają na podniesienie skuteczności tej formy, po pierwsze państwo stosujące groźbę użycia siły musi dokładnie zdawać sobie sprawę czego obawia się przeciwnik. Druga obejmuje także określenie, które działania podjęte przez oponenta doprowadzą do zastosowania wobec niego przemocy zbrojnej oraz co może temu zapobiec. Po trzecie, interesy tych państw nie mogą być całkowicie sprzeczne. Groźbie użycia siły zazwyczaj towarzyszy pokazanie gotowości jej wykonania, co ma przyczynić się do wzrostu jej wiarygodności oraz efektywności. Realizowana jest m.in. w wyniku podniesienia poziomu bojowego części jednostek czy też ich przemieszczenie, mobilizacji sił zbrojnych, ultimatum, np. wyznaczenie ścisłego terminu, tj. dokładnej daty wycofania wojsk $z$ określonego obszaru. ${ }^{38}$

10. Ograniczone użycie siły zbrojnej, w tym także przypadkowe lub upozorowane użycie broni o niskim natężeniu. Zalicza się do nich przegrupowanie i koncentrację wojsk w regionach nadgranicznych, w pobliżu wód terytorialnych, naruszanie przestrzeni powietrznej połączone z groźbą (gotowością) ich użycia. Należą także wskazać na działania nękające poprzez prowokacje graniczne, a także wypady zbrojne i akcje formacji paramilitarnych lub innych grup nieformalnych, które prowadzą akcje o charakterze rozpoznawczym, dywersyjnym lub sabotażowym. Ponadto, w tym przypadku zalicza się także częste użycie robotów wyposażonych w systemy uzbrojenia oraz dronów, tj. bezzałogowych statków lotniczych (BSL), które prowadzą misje zarówno rozpoznawcze jak też bojowe, także nad terytorium innych państw lub strefie przygranicznej. W tym punkcie należy również uwzględnić wszelkie incydenty zbrojne. ${ }^{39}$

11. Wykorzystanie środków niezbędnych do prowadzenia walki informacyjnej, określanej także terminem „wojny informacyjna” lub „wojna cybernetyczna". Wiąże się z atakowaniem przez żołnierzy-hakerów systemów i sieci teleinformatycznych. Nowa forma nie pociąga za sobą bezpośredniego użycia środków bojowych. Jednak w wyniku przeprowadzonych operacji, mogą zostać

${ }^{38}$ J. Kukułka, Zaspokajanie potrzeb i rozwiazywanie konfliktów $w$ stosunkach międzynarodowych..., s. 129-132; J. Kukułka, Wstęp do nauki o stosunkach międzynarodowych, Warszawa 2003, s. 169-172; J. Nowiak, Czym jest polityka zagraniczna..., s. 81; R. Jackson, G. Sørensen, Wprowadzenie..., s. 85-86; T. Łoś-Nowak, Stosunki międzynarodowe. Teorie..., s. 273-278; T. Łoś-Nowak, Polityka zagraniczna ..., s. 89-91; K. Mingst, Podstawy ..., s. 121-122; L. Freedman, S. Raghavan, Wymuszanie, [w:] Studia bezpieczeństwa, P. D. Williams (red.), Kraków 2012, s. 213-223.

${ }^{39}$ W. J. Dziak, Polityka wewnętrzna ..., s. 459; K. Sobczak, Niektóre środki polityki zagranicznej..., s. 102-104; W. Malendowski, Zbrojenia ..., s. 440-441; Ł. Kamieński, Technologia..., s. 262. 
wyrządzone straty znacznie przekraczających użycie konwencjonalnych środków bojowych. W tym przypadku należy uwzględnić ewentualne zakłócenia funkcjonowania sił zbrojnych lub nawet unieszkodliwienia części systemów uzbrojenia. Dodatkowo aktywność ta może wpływać na funkcjonowanie infrastruktury gospodarczej oraz prowadzić do celowej dezinformacji społeczeństwa innego państwa. Działania są prowadzone w sposób zróżnicowany. Po pierwsze, poprzez zablokowanie „wybranych” komputerów, serwerów lub całych sieci, co może doprowadzić do sparaliżowania systemów dowodzenia i obserwacji pola walki oraz ośrodków przekazywania informacji. Szczególnie jest to istotne w przypadku celowego utrudnienia lub zablokowania możliwości funkcjonowania systemu wczesnego ostrzegania i obrony przeciwlotniczej, a także rozpoznania satelitarnego. Po drugie, prowadzenie wojny cybernetycznej obejmuje również z uzyskaniem możliwości dostępu do informacyjnej bazy danych instytucji państwowych. W praktyce w tym przypadku wiąże się z wykradaniem informacji znajdujących się na dyskach komputerów czy też z serwerów, które obejmują wrażliwe dane, m.in. dotyczące bezpieczeństwa innych państw. Uwzględniają również ataki na serwery administracji państwowej. Po trzecie, działania te wiążą się także z preparowaniem, zamieszczaniem lub przekazywaniem fałszywych informacji oraz manipulowanie danymi, np. dotyczących potencjału militarnego lub gotowości bojowej sił zbrojnych. Po czwarte, prowadzenie wojny informacyjnej uwzględnia w swym zakresie także działania psychologiczne, które wiążą się z oddziaływaniem na psychikę decydentów, elit politycznych, społeczeństwa, a także wpływanie na ośrodki kształtowania opinii publicznej innego państwa. Po piąte, $w$ tym przypadku mamy również do czynienia z celowym niszczeniem systemów i środków zabezpieczających systemy informacyjne różnych państw. Do przykładowych konsekwencji aktywności tego rodzaju można zaliczyć zakłócenie funkcjonowania ruchu lotniczego, awarie systemu rafinerii i rurociągów, paraliż działania kolei, niszczenie finansowych baz danych, zakłócenie funkcjonowania satelitów na orbicie, utrudnienia lub zatrzymanie dostaw energii elektrycznej, zakłócanie i przerwanie funkcjonowania sieci telefonii komórkowej..$^{40}$ Prowadzeniem tych działań zajmują się także służby wywiadu lub kontrwywiadu. ${ }^{41}$

12. Użycie sily zbrojnej w szerszym zakresie, po pierwsze, poczynając od inwazji oznaczającej agresję na inne państwo - prowadzenie operacji wojennych. ${ }^{42}$ Po drugie, poprzez działania ekspedycyjne i interwencyjne, $\mathrm{tj}$. interwencje

${ }^{40}$ W. Malendowski, Zbrojenia ..., s. 440-441; J. S. Nye jr., Konflikty międzynarodowe. Wprowadzenie..., s. 348-349; J. Darczewska, Diabet tkwi w szczegółach. Wojna informacyjna w świetle doktryny wojennej Rosji, „Punkt Widzenia OSW”, Warszawa 2015, maj, nr 50, s. 28-30; J. Reginia-Zacharski, Wojna w świecie współczesnym ..., s. 202-203, 261; M. Minkina, Sztuka wywiadu w państwie współczesnym, Warszawa 2014, s. 108-116; Ł. Kamieński, Technologia..., s. 209-342.

${ }^{41}$ M. Minkina, Sztuka..., s. 108.

${ }^{42}$ J. Kukułka, Wstęp do nauki o stosunkach międzynarodowych..., s. 169-172; I. Popiuk-Rysińska, Środki i metody polityki zagranicznej..., s. 87-89; E. Cziomer, L. W. Zyblikiewicz, Zarys..., s. 139; R. Łoś, Teoria stosunków międzynarodowych. Wybrane zagadnienia, Łódź 2001, 
zbrojne, które z jednej strony mogą pociągać za sobą wykorzystanie siły zbrojnej w celu m.in. zajęcia terytorium drugiego państwa, ewentualnie tylko jego części, ale nie towarzyszą im walki lub ich natężenie pozostaje na stosunkowo niskim poziomie. Kwestia ta obejmuje ingerencję w sytuację wewnętrzną w danym państwie i może wiązać się ze wsparciem dla jednej ze stron, tj. obozu władzy lub antyrządowego. Interwencja zbrojna podejmowana jest na prośbę strony, która postrzega zagrożenie, tj. władz lub opozycji. Należy także uwzględnić zaangażowanie wojskowe w celu zwalczania grup nieformalnych (partyzantów i powstańców) i organizacji terrorystycznych na terytorium innych państw. ${ }^{43}$ Po trzecie, do tej kategorii zalicza się również zaplanowane ataki na terytorium drugiej strony czy też na jednostki wojskowe, bez wkraczania na obszar innego państwa. Po czwarte, należy uwzględnić także wykorzystanie sił zbrojnych w celu blokady morskiej portów lub wybrzeża przeciwnika przy wykorzystaniu okrętów wojennych, lotnictwa czy też lądowej - zastosowanie tzw. „kordonu sanitarnego”. ${ }^{44}$ Obecnie w coraz większym stopniu siły zbrojne wykorzystują bojowe bezzałogowe statki latające do bezpośrednich działań zbrojnych..$^{45}$

13. Udział w operacjach pokojowych stanowi specyficzną formę wykorzystania siły militarnej jako instrumentu polityki zagranicznej państwa. Obejmuje on tylko te misje, które są prowadzone na podstawie decyzji Rady Bezpieczeństwa Narodów Zjednoczonych lub innych regionalnych organizacji odpowiedzialnych za utrzymanie bezpieczeństwa zbiorowego. Wliczając także interwencje, zarówno w celu odparcia agresji oraz w celach humanitarnych. Uzupełniają je operacje stabilizacyjne. ${ }^{46} \mathrm{~W}$ ramach operacji pokojowych, siły zbrojne koncentrują się na

s. 40-41; J. Nowiak, Czym jest polityka zagraniczna..., s. 81; J. Zając, Środki i metody polityki zagranicznej państwa..., s. 88-90; J. Zając, Środki i metody oddziaływania USA ..., s. 22-24; S. Burchill, R. Devetak, A. Linklater, M. Paterson, Ch. Reus-Smit, J. True, Teorie ..., s. 97-98, 247; R. Jackson, G. Sørensen, Wprowadzenie do stosunków międzynarodowych. Teorie i kierunki badawcze, Kraków 2006, s. 78; L. Freedman, Przyszłość studiów strategicznych, [w:] Strategia we współczesnym świecie. Wprowadzenie do studiów strategicznych, J. Baylis, J. Wirtz, C. S. Gray, E. Cohen (red.), Kraków 2009, s. 401-402; A. Wendt, Spoteczna ..., s. 263-266; J. Reginia-Zacharski, Wojna w świecie współczesnym ..., s. 130 i nast.; P. Żurawski vel Grajewski, Bezpieczeństwo międzynarodowe..., s. 59-73.

${ }^{43}$ J. Kukułka, Wstęp do nauki o stosunkach międzynarodowych, Warszawa 2003, s. 169-172; I. Popiuk-Rysińska, Środki i metody polityki zagranicznej..., s. 87-89; R. Łoś, Teoria stosunków międzynarodowych..., s. 40-41; J. Nowiak, Czym jest polityka zagraniczna..., s. 81; M. Dobroczyński, J. Stefanowicz, Polityka ..., s. 135-142; P. Żurawski vel Grajewski, Bezpieczeństwo międzynarodowe..., s. 77-79; K. Derwich, Instrumenty ..., s. 55-90; P. D. Williams, Wojna, [w:] Studia bezpieczeństwa, P. D. Williams (red.), Kraków 2012, s. 161-165; P. R. Pillar, Przeciwdziałanie terroryzmowi, [w:] Studia bezpieczeństwa, P. D. Williams (red.), Kraków 2012, s. 385-388; M. van Creveld, Zmienne ..., s. 269-317; R. Smith, Przydatność..., s. 195-196.

${ }^{44}$ I. Popiuk-Rysińska, Środki i metody polityki zagranicznej..., s. 87-89; R. Łoś, Teoria stosunków międzynarodowych ..., s. 40-41; R. Smith, Przydatnośćc..., s. 455-457.

${ }^{45}$ W. Malendowski, Zbrojenia ..., s. 440-441.

${ }^{46}$ R. Kuźniar, Międzynarodowe stosunki polityczne..., s. 117-118; T. Łoś-Nowak, Stosunki międzynarodowe. Teorie..., s. 280; T. Łoś-Nowak, Polityka zagraniczna..., s. 93; T. Farrell, Inter- 
odbudowie i rekonstrukcji, misjach stabilizacyjnych, szkoleniu i doradztwie wojskowym, tj. podnoszenia kwalifikacji personelu wojskowego i funkcjonariuszy innych służb, nadzorowanie przestrzegania wprowadzonego embarga lub sankcji, m.in. związanych z dostawami techniki wojskowej. Odstraszanie i wywieranie nacisku, które przewiduje możliwość zastosowania sił zbrojnych w sytuacji pojawienia się zagrożenia. Ostatnia kwestia wiąże się z przeprowadzaniem ataków, które zakłada niszczenie potencjału militarnego przeciwnika. ${ }^{47} \mathrm{~W}$ tym punkcie istotną kwestię stanowi charakter i poziom zaangażowania wojskowego poszczególnych państw.

14. Prowadzenie dzialalności wywiadowczej, wiąże się z wykorzystaniem wywiadu osobowego, jak również elektronicznego, do realizacji różnych tajnych akcji. Aktywność ta koncentruje się na wykonywaniu działań, do których zalicza się:

a) zdobywanie informacji, a następnie wykorzystanie na potrzeby własnego państwa. Z jednej strony wiążą się ze zbieraniem, przetwarzaniem, selekcją $i$ analizą materiałów jawnych uzyskanych poprzez wszystkie istniejące i dostępne źródła informacji, tzw. biały wywiad. Po drugie, wykorzystanie nielegalnych metod $\mathrm{w}$ celu pozyskania ściśle tajnych informacji ze źródeł alternatywnych. Należy także w tym punkcie uwzględnić tzw. „wywiad gospodarczy". Wywiad także ma na celu zbieranie informacji dotyczących potencjału militarnego oraz zdolności bojowych sił zbrojnych innych państw ${ }^{48}$

b) prowadzenie - tajnej - dzialalności propagandowej, zarówno o charakterze pozytywnym, jak i negatywnym, określanej jako tzw. czarna propaganda, wobec innych państw lub samych polityków m.in. poprzez ich oczernianie. Działania te wiążą się także z oddziaływaniem na stanowisko i sposób myślenia społeczeństw wybranych państw. Ponadto istotne miejsce zajmuje dezinformacja;

c) uzyskanie wpływów pośród przedstawicieli władz, co może wiązać się z umiejscowieniem ,agentury” w ośrodku decyzyjnym drugiej strony. Ponadto, w zakresie zainteresowania znajdują się elity polityczne, gospodarcze i intelektualne innych państw. Pozyskiwanie agentów lub

wencje humanitarne i operacje pokojowe, [w:] Strategia we wspótczesnym świecie. Wprowadzenie do studiów strategicznych, J. Baylis, J. Wirtz, C. S. Gray, E. Cohen (red.), Kraków 2009, s. 356-364; J. Reginia-Zacharski, Wojna w świecie wspótczesnym ..., s. 224-232, 308-314; P. Żurawski vel Grajewski, Bezpieczeństwo międzynarodowe..., s. 137-155, 239-240, 257-275, 279-289; A. Jones, Ludobójstwo i masowe mordy, [w:] Studia bezpieczeństwa, P. D. Williams (red.), Kraków 2012, s. 187-190; S. J. Kaufman, Konflikty etniczne, [w:] Studia bezpieczeństwa, P. D. Williams (red.), Kraków 2012, s. 208-211; L. Fawcett, Instytucje regionalne, [w:] Studia bezpieczeństwa, P. D. Williams (red.), Kraków 2012, s. 315-317; T. G. Weiss, D. Z. Kalbacher, Organizacja Narodów Zjednoczonych, [w:] Studia bezpieczeństwa, P. D. Williams (red.), Kraków 2012, s. 336-338; M. Pugh, Operacje pokojowe, [w:] Studia bezpieczeństwa, P. D. Williams (red.), Kraków 2012, s. 412-421; R. Smith, Przydatność..., s. 119-121, 352, 369-379, 393-437; A. Żebrowski, Wywiad..., s. 264-2.

${ }^{47}$ R. Smith, Przydatność..., s. 379-384.

${ }^{48}$ M. Minkina, Sztuka..., s. 38-39. 
współpracowników jest możliwe poprzez przekupienie, korumpowanie, szantaż, sympatie ideologiczne. Kwestia ta może wiązać się z infiltracją aparatu władzy i systemu obronnego innego państwa;

d) wspieranie w sposób niejawny zaprzyjaźnionych państw, które może obejmować $\mathrm{m}$.in. zapewnienie bezpieczeństwa określonym przedstawicielom władz lub politykom, wsparcie wywiadowcze;

e) działania o charakterze wywrotowym (dywersyjne), m.in. poprzez sabotaże, stymulowanie i wspieranie strajków, pomoc dla obozu opozycji, organizowanie zamachów stanu, przewrotów i puczów wojskowych, które mają na celu także obalanie rządów;

f) finansowanie oraz kontrola funkcjonowania i działalności organizacji społecznych;

g) działalność kontrwywiadowcza związana z ochroną własnego państwa przed infiltracją przez obce wywiady oraz rozpoznanie ich metod i środków funkcjonowania. Reasumując, wywiad koncentruje się na zdobywaniu informacji o potencjale przeciwnika oraz o jego zamiarach. ${ }^{49}$

$\mathrm{Z}$ jednej strony prowadzenie działalności wywiadowczej wpływa na kształtowanie sytuacji politycznej, gospodarczej, militarnej w innym państwie lub środowisku międzynarodowym. Po drugie, tajne działania stosuje się wówczas, gdy inne instrumenty polityki zagranicznej są nieskuteczne, zaś pozostałe formy wykorzystania instrumentu militarnego z określonych powodów staje się niemożliwe lub nieopłacalne. ${ }^{50}$

Do sprawnego funkcjonowania sił zbrojnych oraz prowadzenia operacji, a niezbędne jest zdobywanie i selekcja i analiza zgromadzonych informacji dotyczących przeciwnika a także oceny sytuacji międzynarodowej. Działania wywiadu stanowią jeden z priorytetów działania współczesnych armii. ${ }^{51}$ Wywiad za obszar swojego działania określa zbieranie informacji dotyczących zagrożeń dla bezpieczeństwa państwa, ale także rozpoznawania tych zagrożeń, w tym tych ze strony podmiotów niepaństwowych. Działalność jego koncentruje się przede wszystkim poza granicami państwa. ${ }^{52}$ Wywiad stanowi jeden ze sposobów działania państwa służący do walki z przeciwnikiem, który do tego celu używa „informację jako obszar i instrument tej walki". ${ }^{53}$

${ }^{49}$ I. Popiuk-Rysińska, Środki i metody polityki zagranicznej..., s. 87-89; J. Zając, Środki i metody polityki..., s. 94-97; J. Zając, Środki i metody oddziaływania..., s. 28-30; K. Sobczak, Niektóre środki polityki zagranicznej..., s. 107-109; E. J. Pałyga, Uczestnicy stosunków międzynarodowych..., s. 79-82; J. S. Nye jr., Konflikty międzynarodowe. Wprowadzenie..., s. 347-349; K. Derwich, Instrumenty..., s. 101-104; R. Szpyra, Bezpieczeństwo militarne państwa ..., s. 120-129, 154-159; M. van Creveld, Zmienne..., s. 328; R. Smith, Przydatność..., s. 384-389; M. Minkina, Sztuka wywiadu w państwie wspótczesnym, Warszawa 2014, s. 31 i nast.; A. Żebrowski, Wywiad..., s. 20 i nast.

${ }^{50}$ M. Minkina, Sztuka..., s. 44.

${ }^{51}$ R. Smith, Przydatność..., s. 460-461, 471-473.

${ }_{52}$ M. Minkina, Sztuka..., s. 16-18.

${ }^{53}$ M. Minkina, Sztuka..., s. 33-34. 
Przyjęte we wstępie hipotezy potwierdziły się, a mianowicie, po pierwsze, formy wykorzystania instrumentu militarnego polityki zagranicznej państwa są dynamicznym procesem i ulegają stopniowemu poszerzeniu. Po drugie, mimo iż dominują pośrednie formy wykorzystania instrumentu militarnego, to jednak pojawiają się nowe możliwości, w tym związane z bezpośrednim użyciem sił zbrojnych o niskiej intensywności, tj. poniżej progu wojny. Stopniowo od początku XXI wieku wzrasta rola siły militarnej. Sytuacja ta wynika w znacznym stopniu od wzrostu znaczenia podmiotów niepaństwowych.

\title{
MILITARY INSTRUMENTS OF STATE'S FOREIGN POLICY
}

\begin{abstract}
Importance of military power has been limited after the cold-war. Range of military instrument underwent gradual broadening. Significant influence on this situation has been exerted by both new technology and new armament systems but also by the growth of non-state actors. The latest actors are more threat to the societies than to states. This problem has affected a form of utilization of military instrument in foreign policy of states.

The article includes analysis of notion ,military instrument”. Forms of implementation of military instruments in foreign policy of states has been characterized also. Two hypotheses are subject of verification. The first, forms of implementation of military instruments of foreign policies of states are dynamic process and they undergo gradual widening. The second, although indirect forms of implementation of military instruments predominate, however, it appear new possibilities of direct use of military instruments in low intensity conflicts, i.e. below threshold of war.
\end{abstract}

Key words: state, foreign policy, military instruments 